\title{
SELECTIVITY OF INSECTICIDES USED IN PEACH FARMING TO LARVAE OF Chrysoperla externa (NEUROPTERA: CHRYSOPIDAE) IN SEMI-FIELD CONDITIONS ${ }^{1}$
}

\author{
RODOLFO VARGAS CASTILHOS ${ }^{2 *}$, ANDERSON DIONEI GRÜTZMACHER ${ }^{3}$, MÁRCIO BARTZ DAS \\ NEVES ${ }^{3}$, ÍTALO LUCAS DE MORAES ${ }^{3}$, CLEITON JAIR GAUER ${ }^{3}$
}

\begin{abstract}
The selectivity of five insecticides, regularly used in peach farming, was assessed for larvae of the predator Chrysoperla externa (Hagen) (Neuroptera: Chrysopidae) by means of bioassay in semi-field conditions. The bioassay was based on the counting of captured larvae after release in peach trees treated with the insecticides (\% of active ingredient in spray liquid): deltamethrin (0.001), fenthion (0.050), phosmet (0.100), lufenuron (0.005) and malathion (0.200). Bait-cards with eggs of Anagasta kuehniella (Zeller) (Lepidoptera: Pyralidae) were used to capture larvae from treated plants; five of them were fixed in plant canopy and five others left on the soil around stem. A protective barrier made up of galvanized steel sheet was used for each plant to avoid loss of larvae. The number of larvae feeding on the bait-cards was measured for four days. According to the number of captured larvae, each insecticide effect was estimated and classified into toxicity categories as stated by the International Organization for Biological and Integrated Control of Noxious Animals and Plants (IOBC). Based on observations, the insect growth regulator lufenuron was harmless, while the neurotoxins deltamethrin and malathion were slightly harmful; and lastly, fenthion and phosmet were moderately harmful to C. externa larvae in semi-field conditions. Thus, lufenuron should be recommended for integrated pest management, since it would preserve this predator species in peach orchards.
\end{abstract}

Key words: Biological control. Lacewings. Chemical control. Prunus persica L..

\section{SELETIVIDADE DE INSETICIDAS EMPREGADOS NA PERSICULTURA PARA LARVAS DE Chrysoperla externa (NEUROPTERA: CHRYSOPIDAE) EM SEMICAMPO}

RESUMO - A seletividade de cinco inseticidas utilizados em pomares de pessegueiro foi avaliada sobre larvas do predador Chrysoperla externa (Hagen) (Neuroptera: Chrysopidae) por meio de bioensaio conduzido em semicampo. O bioensaio baseou-se na contagem do número de larvas capturadas após liberação em plantas de pessegueiro tratadas com os inseticidas (\% de ingrediente ativo na calda) deltametrina $(0,001)$, fentiona $(0,050)$, fosmete $(0,100)$, lufenurom $(0,005)$ e malationa $(0,200)$. Para captura das larvas nas plantas tratadas foram utilizados dez cartões-isca contendo ovos de Anagasta kuehniella (Zeller) (Lepidoptera: Pyralidae), sendo cinco fixados na copa e cinco fixados no solo ao redor do caule. Uma barreira de proteção composta por chapa de aço galvanizado foi utilizada em cada planta para evitar a perda de larvas. O número de larvas alimentando-se nos cartões foi mensurado durante quatro dias. Em função do número de larvas capturadas, o efeito de cada inseticida foi calculado e classificado nas categorias de toxicidade segundo a "International Organization for Biological and Integrated Control of Noxious Animals and Plants" (IOBC). Baseado no efeito observado, o regulador de crescimento lufenurom foi inofensivo, enquanto os neurotóxicos deltametrina e malationa foram pouco tóxicos, e fentiona e fosmete foram moderadamente tóxicos a larvas de C. externa em condições de semicampo. Desta forma, lufenurom deve ser recomendado no manejo integrado de pragas a fim de se preservar esta espécie de predador em pomares de pessegueiro.

Palavras-chave: Controle biológico. Crisopídeo. Controle químico. Prunus persica L..

\footnotetext{
*Corresponding author

${ }^{1}$ Received for publication in $07 / 08 / 2015$; accepted in 06/16/2016.

Paper extracted from the doctoral thesis of the first author, Funded by CAPES, CNPq and FAPERGS.

${ }^{2}$ Research Center for Family Farming, Empresa de Pesquisa Agropecuária e Extensão Rural de Santa Catarina, Chapecó, SC, Brazil; rodolfocastilhos@epagri.sc.gov.br.

${ }^{3}$ Department of Crop Protection, Universidade Federal de Pelotas, Pelotas, RS, Brazil; adgrutzm@ufpel.edu.br, mbdasneves@hotmail.com, italolucasmoraes@gmail.com, cleitonjgauer@gmail.com.
} 


\section{INTRODUCTION}

Among the damaging factors in peach yields in Brazil, it is noteworthy mention the infestations of pest-insects such as fruit flies Anastrepha fraterculus (Wied.) and Ceratitis capitata (Wied.) (Diptera: Tephritidae), as well as oriental fruit moth Grapholita molesta (Busck) (Lepidoptera: Tortricidae) and secondary pests like aphids, mites and mealybugs (NAVA et al., 2014). Most peach growers still use chemical control, applying broad-spectrum insecticides regularly, such as organophosphates and pyrethroids, as main control tactics against these insects (BOTTON et al., 2011). However, indiscriminate use of insecticides can adversely affect natural enemies in the orchards, impairing thus the natural biological control besides encouraging rise of species already under control (ATANASSOV; SHEARER; HAMILTON, 2003).

Predatory insects from the family Chrysopidae naturally occur in various agricultural ecosystems, including peach orchards (SCHUBER et al., 2008). Among the lacewing species, Chrysoperla externa (Hagen) (Neuroptera: Chrysopidae) is the most abundant and has been widely studied in the Neotropics due to its high potential for use in biological control programs (ALBUQUERQUE; TAUBER; TAUBER, 1994). This predator is notable for regulating populations of several phytophagous insects in peach crop areas, feeding on eggs and small larvae of lepidopterans, mites, aphids and mealybugs (FREITAS, 2002; DE BORTOLI et al., 2006). Thus, the maintenance of $C$. externa populations in peach orchards should be consistently considered. To this end, the use of selective pesticides or with low impact on this predator is of upmost importance. Therefore, it becomes necessary further surveys on insecticide selectivity to this species.

Studies on pesticide selectivity to $C$. externa have been carried out in Brazil for several crops; however, the vast majority of these studies were made under laboratory conditions (GODOY et al., 2010; MOURA et al., 2010; VILELA et al., 2010). Concerning peach orchards, laboratorial studies on pesticide selectivity to $C$. externa have been performed for larval (CASTILHOS et al., 2013) and adult (CASTILHOS et al., 2011) stages. Nonetheless, there are no records of selectivity studies to date in neither semi-field nor field conditions with this species in peach trees, which might be due to the high cost and difficulty of such studies.

It is relevant to assess pesticide toxicity on non-target organisms, both in conditions of semi-field or field, as it provides definitive information about the real impact of a product against a given natural enemy (THOMSON; HOFFMANN, 2006).

In this sense, this study aimed at evaluating the selectivity of five insecticides, commonly used in peach orchards, to larvae of the predator C. externa under semi-field conditions.

\section{MATERIAL AND METHODS}

The bioassay was carried out in an experimental area belonging to the Federal University of Pelotas (Universidade Federal de Pelotas - UFPel) located in Capão-do-Leão-RS, Brazil (31 ${ }^{\circ} 52^{\prime} \mathrm{S}$ latitude, 52 $21^{\prime} \mathrm{W}$ longitude), according scientific approach proposed by Vogt (1994) and Viñuela, Händel and Vogt (1996).

The larvae of $C$. externa were obtained from a colony kept in laboratory (temperature at $25 \pm 1^{\circ} \mathrm{C}$, relative humidity of $70 \pm 10 \%$ and photophase of 14 hours). Each larva was fed on nearly $0.06 \mathrm{~g}$ of Anagasta kuehniella (Zeller) (Lepidoptera: Pyralidae) eggs and adults had an artificial diet as described by Vogt et al. (2000).

Table 1 describes the insecticides assessed under semi-field conditions, which had shown to be harmful to $C$. externa larvae through a previous lab study (CASTILHOS et al., 2013). These products are recommended to control oriental fruit moth, fruit flies and aphids in peach growing areas (AGROFIT, 2016); they were tested at their highest dosages recommended by manufacturers for pest control in peach orchards. As control treatment, only distilled water was sprayed.

Table 1. Insecticides used in peach orchards and tested on larvae of Chrysoperla externa in semi-field bioassay.

\begin{tabular}{lccccc}
\hline Commercial product & Active ingredient & Chemical group & D.C. $^{1}$ & C.a.i. $^{2}$ & C.c.f. $^{3}$ \\
\hline Decis 25 EC & Deltamethrin & Pyrethroid & 40 & 0.001 & 0.040 \\
Imidan 500 WP & Phosmet & Organophosphate & 200 & 0.100 & 0.200 \\
Lebaycid 500 & Fenthion & Organophosphate & 100 & 0.050 & 0.100 \\
Malathion 1000 EC & Malathion & Organophosphate & 200 & 0.200 & 0.200 \\
Match EC & Lufenuron & Benzoylurea & 100 & 0.005 & 0.100 \\
\hline
\end{tabular}

${ }^{1}$ D.C. $=$ Dosage of commercial formula $\left(\mathrm{g}\right.$ or $\left.\mathrm{mL} 100 \mathrm{~L}^{-1}\right) ;{ }^{2}$ C.a.i. = Concentration $(\%)$ of active ingredient tested;

${ }^{3}$ C.c.f. $=$ Concentration $(\%)$ of the tested commercial formula. 
The insecticides were sprayed at the previously mentioned dosages on peach trees of nearly $1.5 \mathrm{~m}$ of height through a $\mathrm{CO}_{2}$-pressurized sprayer with a uniform flat jet nozzle (Teejet XR110015EVS), until leaf runoff, which corresponded to a volume of about $0.4 \mathrm{~L}$ spray plant $^{-1}$. Treatments consisted of four plants distributed in a random block experimental design.

A barrier made of galvanized steel sheet $(1.60 \times 1.60$ meters $)$ with an opening in the middle through which plant stem passed protected each plant (Figure 1A). A thin layer of dry sieved soil was spread over the galvanized steel sheet.

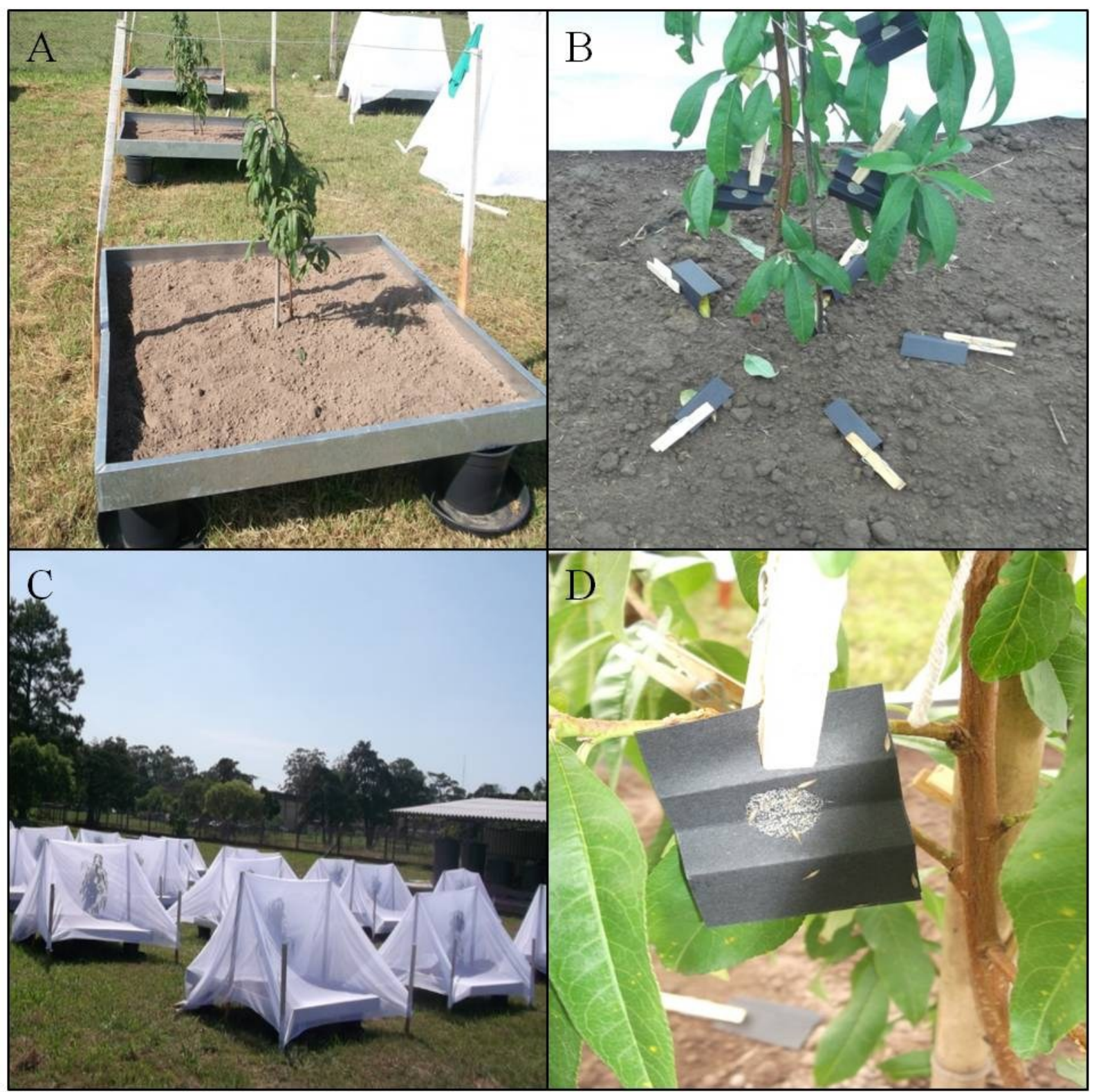

Figure 1. Details of semi-field bioassay with larvae of Chrysoperla externa. (A) Protective barrier composed of galvanized steel sheet around peach plant; (B) Distribution of bait-cards with eggs of Anagasta kuehniella for larval capture; (C) Plant covered with voile-type fabric; (D) Larvae of $C$. externa captured on bait-cards.

After spray drying (2-h later), 200 second instar C. externa larvae were released on each plant, and shortly thereafter, ten cardboards $(5 \times 7 \mathrm{~cm})$, containing $400 \pm 50$ eggs of A. kuehniella (around 4,000 eggs), were placed on treatments to serve as attractive trap for larval capturing. Five of them were fixed on soil surrounding tree stem, and the other five were hung from branches by a clip (Figure 1B), being replaced daily until the end of the evaluations.
To avoid predation by birds or losses by intense winds and rainfalls, the plants were protected with a voile-type fabric (Figure 1C).

Four pillars supported the protective barrier, as displayed in Figure 1A. Each pillar was fixed in a container with water, which was used to prevent ants and other insects to climb up the stem and feed on $C$. externa larvae and A. kuehniella eggs. In turn, the protective barrier enabled the larvae released on 
plants to behave naturally, moving up and downward along the plant stem.

Counting was performed daily for the four first days after spraying, checking the number of larvae on each bait-card with eggs of $A$. kuehniella (Figure 1D). The larvae were removed from bait-cards using a fine-bristle paintbrush, counted and subsequently released back onto the plant canopy, viewing to put them in contact with the pesticide residue again.

The number of captured larvae per tree of each treatment was taken into account for insecticide effect calculation. Such calculation was made through the following formula: $\mathrm{E} \%=100 \times[(\mathrm{C}-\mathrm{T}) / \mathrm{C}]$, wherein $\mathrm{E} \%=$ Effect $(\%)$; $\mathrm{C}=$ average number of larvae captured in control and $\mathrm{T}=$ average number of larvae captured in treated plants (ABBOTT, 1925).

According to the effect $(\mathrm{E} \%)$, insecticides were rated into toxicity categories for semi-field bioassays established by the International
Organization for Biological and Integrated Control of Noxious Animals and Plants (IOBC), which are: 1) harmless $(<25 \%)$; 2) slightly harmful $(25-50 \%)$; 3) moderately harmful (51-75\%) and 4) harmful $(>75 \%)$. Data regarding the number of captured larvae per treatment underwent variance analysis, and the means were compared by the Tukey's test, at $5 \%$ probability, using Winstat software (MACHADO; CONCEIÇÃ̃, 2007).

\section{RESULTS AND DISCUSSION}

Among the evaluated insecticides, Figure 2 shows that deltamethrin, fenthion, malathion and phosmet reduced the number of captured larvae on the first day after release (1 DAR) $(\mathrm{F}=6.86, \mathrm{df}=5, p=0.00096)$. Captures ranged from 15.3 to 22.5 by treatment with fenthion and malathion respectively, showing a reduction of more than $50 \%$ compared to control.

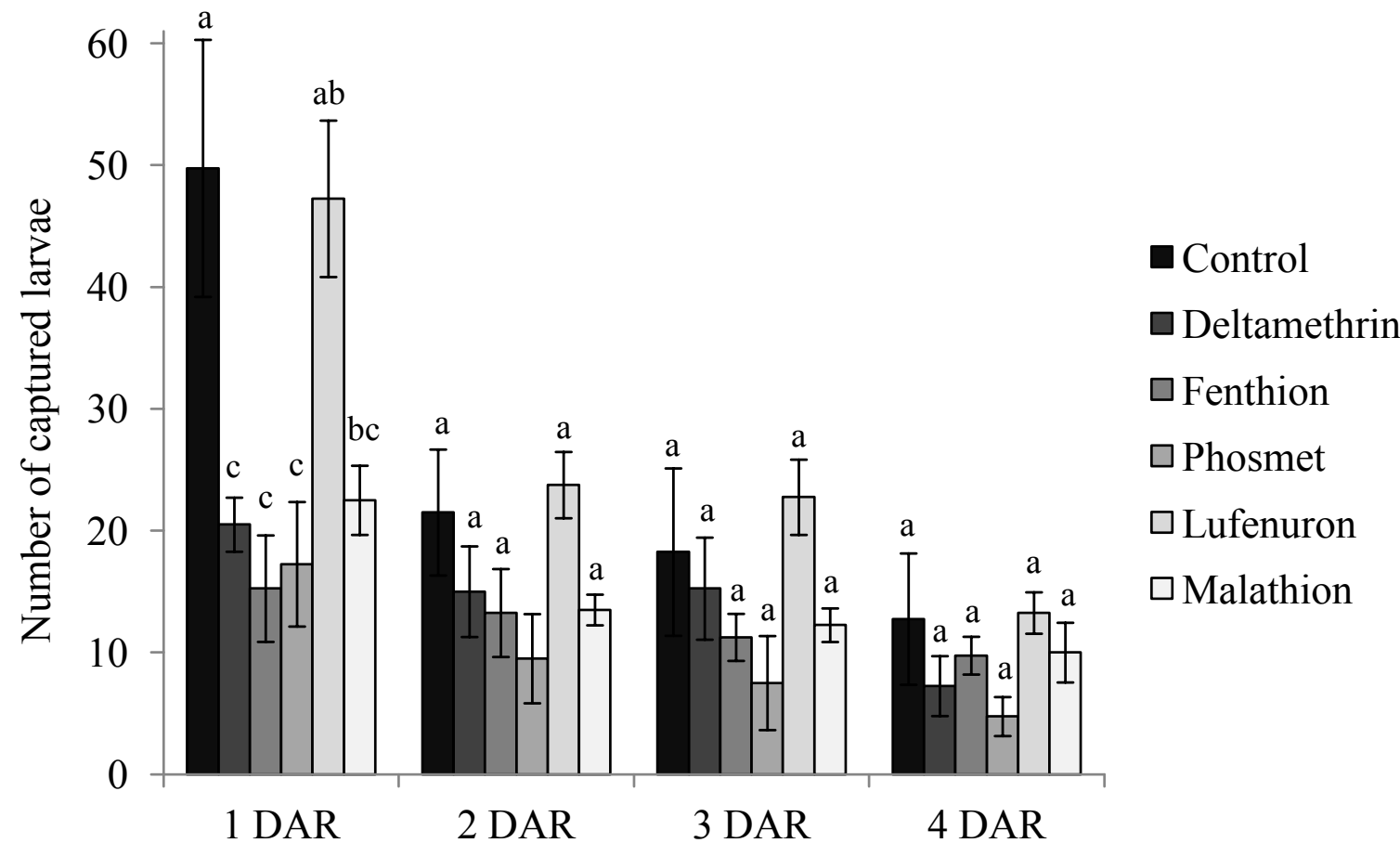

Figure 2. Average number ( \pm standard error) of Chrysoperla externa larvae captured during the four-day trial in peach plants sprayed with insecticides under semi-field conditions.

Means followed by different letters each day after release (DAR) differ significantly by the Tukey's test at 5\% probability.

At 1, 2, 3 and 4 DAR, 47.3, 23.8, 22.8 and 13.3 larvae were captured for treatment with lufenuron, respectively. These averages were not significantly different from those observed in control, which were 49.8, 21.5, 18.3 and 12.8 larvae collected, respectively (Figure 2).

At 2, 3 and 4 DAR, the number of captured larvae in treatments with deltamethrin, fenthion, malathion and phosmet had no difference from lufenuron or control ( 2 DAR: $F=2.32 ; \mathrm{df}=5$; $p=0.085 ; 3$ DAR: $\mathrm{F}=1.86 ; \mathrm{df}=5 ; p=0.15$; 4 DAR: $\mathrm{F}=1.28 ; \mathrm{df}=5 ; p=0.31$ ) (Figure 2).

With respect to insecticide effect and toxicity classification, Table 2 shows that the average number of larvae captured during the four-day trial in plants sprayed with the organophosphate insecticides fenthion and phosmet were significantly lower than control $(\mathrm{F}=6.05 ; \mathrm{df}=5 ; p<0.0001)$. 
These aforementioned insecticides were classified as moderately harmful (class 3), with an effect of 51.6 and $61.9 \%$ on larvae, respectively. The pyrethroid deltamethrin and the organophosphate malathion reached similar effect, reducing in approximately
$43 \%$ the capture of larvae, being therefore classified as slightly harmful (class 2). The insect growth regulator lufenuron did not reduce the average number of captured larvae, and was considered harmless (class 1).

Table 2. Average number ( \pm standard error) of captured Chrysoperla externa larvae, effect and IOBC toxicity class of the assessed insecticides under semi-field conditions.

\begin{tabular}{lcccc}
\hline Treatment & D.C. & $\boldsymbol{n} \pm \mathbf{S E}^{*}$ & $\mathbf{E \%}^{\mathbf{2}}$ & $\mathbf{C}^{\mathbf{3}}$ \\
\hline Control & - & $25.6 \pm 4.9 \mathrm{ab}$ & - & - \\
Deltamethrin & 40 & $14.5 \pm 1.9 \mathrm{bc}$ & 43.3 & 2 \\
Fenthion & 100 & $12.4 \pm 1.5 \mathrm{c}$ & 51.6 & 3 \\
Phosmet & 200 & $9.8 \pm 2.1 \mathrm{c}$ & 61.9 & 3 \\
Lufenuron & 100 & $26.8 \pm 3.7 \mathrm{a}$ & 0.0 & 1 \\
Malathion & 200 & $14.6 \pm 1.5 \mathrm{bc}$ & 43.0 & 2 \\
\hline
\end{tabular}

${ }^{1}$ D.C. $=$ Dosage of commercial formula $\left(\mathrm{g}\right.$ or $\left.\mathrm{mL} 100 \mathrm{~L}^{-1}\right) ;{ }^{2} \mathrm{E} \%$ (Insecticide effect) $=100 \mathrm{x}[(\mathrm{C}-\mathrm{T}) / \mathrm{C}]$, wherein $\mathrm{C}=$ average number of larvae captured in control and $\mathrm{T}=$ average number of larvae captured in treated plants (ABBOTT, 1925); ${ }^{3}$ IOBC toxicity classification for semi-field trial: $1=$ harmless $(<25 \%) ; 2$ = slightly harmful (25-50\%); 3 = moderately harmful (51-75\%); 4 = harmful (> 75\%).

* Means followed by different letters differ significantly by the Tukey's test at $5 \%$ probability.

Either the pyrethroid deltamethrin or the organophosphates fenthion, phosmet and malathion are featured by a knockdown effect and, thus, acting faster by causing symptoms such as shivering, reduced movement, regurgitation and excessive excretion in insects (HARAMBOURE et al., 2013). Differently, lufenuron interfere in the molting by inhibiting chitin synthesis (ADEL, 2012), which may explain the difference from neurotoxic insecticides at 1 DAR.

An insect population survival is affected by environmental resistance, which is responsible for natural mortality caused by adverse weather conditions among others as biotic actions of parasitoids, predators and pathogens, as well as lack or poor quality of hosts (PETERSON et al., 2009). Therefore, covering the plants with voile-type fabric (Figure 1C) was crucial since played down weather action such as rainfall and winds. Between the first and the second DAR, rainfall of $22 \mathrm{~mm}$ poured down and the cloth could not avoid leaf wetting but prevented larvae and bait-cards to suffer direct impact from raindrops. The decreasing number of captured larvae at 2, 3 and 4 DAR, in all treatments, may be partly related to rainfall, however, evaluations of insecticidal effect on larvae was not impaired, since all treatments underwent the same environmental actions.

The number of larvae collected in control over the four-day evaluation closely resembles that achieved by Viñuela, Händel and Vogt (1996) running a field bioassay conducted in a similar manner to this study, with a protective barrier. These authors collected in the first catch around 20\% from larvae of Chrysoperla carnea (Stephens) (Neuroptera: Chrysopidae) released onto untreated apple trees, with a decreasing rate as the days passed.

Evaluating the effect of a natural pyrethrin-based insecticde under field conditions, Viñuela, Händel and Vogt (1996) found non-harmful effect against larvae of $C$. carnea, and classified it as harmless (class 1). These authors claimed that such finding was due to low persistence of natural pyrethrin, since they are easily susceptible to photo-degradation compared to synthetic ones.

Conversely to this study, where deltamethrin was considered slightly toxic (class 2 ) to C. externa, Vogt (1994) confirmed high toxicity of cyfluthrin, also a pyrethroid, to $C$. carnea larvae, rating it as harmful (class 4). The same author evaluated phosmet and classified as harmless (class 1) to $C$. carnea, with only $10.5 \%$ reduction in larvae capture, whereas it was moderately harmful (class 3 ) to $C$. externa, in the present study. These differences may derive from active ingredient intrinsic characteristics, whose levels of toxicity may vary within a chemical group, type of formulation, presence of inert and adjuvant ingredients and different dosages (KALAMARAKIS; MARKELLOU, 2007). Differences in susceptibility between species can also interfere with toxicity of the insecticides in question, as these species have different enzyme detoxification systems. $C$. carnea tolerance to certain pesticides, particularly pyrethroids, is attributed, among others, to high activity of esterase enzymes (MULLIGAN et al., 2010); while for C. externa, the P450 monoxygenases, another enzyme group, acts jointly with esterases and provides a degree of natural tolerance to pyrethroids (HARAMBOURE, 2016). Furthermore, the use of different leaf substrates, apple in the study of Vogt (1994), may have effect on the results. As stated by Zongmao and Haibin (1997), leaf substrate can influence insecticide toxicity, since active ingredient metabolization and concentration into the leaves may vary depending on species intrinsic features, for 
example hairiness, roughness and leaf growth rate.

Some populations of lacewings show a certain degree of tolerance to neurotoxic insecticides, with no deleterious effects on biotic potential and predating ability (PATHAN et al., 2008; PATHAN et al., 2010; HARAMBOURE et al., 2013), which makes them an important choice for programs where biological and chemical control are required. Under conditions where spraying of neurotoxic insecticides becomes extremely necessary in peach orchards, deltamethrin or malathion are the most rational choice for maintenance of $C$. externa, since these products were the least harmful to this predator larvae among the neurotoxic insecticides evaluated.

Likewise to the current study where lufenuron proved a harmless effect, Haramboure (2016) found high selectivity of the insect growth regulator pyriproxyfen to $C$. externa, demonstrating selectivity of such class of insecticides to the referred predator larvae.

According to Thomson and Hoffmann (2006), lacewings are extensively exposed to pesticides, thus the use of selective insecticides as stated by selectivity tests of the IOBC contributes to maintaining and preserving these natural enemies in agricultural ecosystems. Under this background, it is essential to identify selective insecticides to $C$. externa and incorporate them into Integrated Pest Management programs (IPM) to ensure this species biological control in peach orchards.

Selectivity studies under conditions of semi-field or field, which are able to provide most realistic information on impacts of pesticides against natural enemies, are still scarce, mainly due to methodological issues.

Despite the advances brought by the IPM, chemical control of pest insects in peach orchards is, in several cases, still necessary, of which selective active ingredients to natural enemies must be prioritized. This way, the insect growth regulator, lufenuron, which has proven to be harmless to $C$. externa larvae, should be recommended for Integrated Pest Management programs in peach growing areas, aiming to preserve such important predator species.

\section{CONCLUSIONS}

Lufenuron is harmless (class 1), deltamethrin and malathion are slightly harmful (class 2), and fenthion and phosmet are moderately harmful (class 3) to larvae of C. externa under semi-field conditions.

The insect growth regulator, lufenuron, must be prioritized to replace neurotoxic insecticides in peach orchards, seeking to maintain the populations of C. externa.

\section{REFERENCES}

ABBOTT, W. S. A method of computing the effectiveness of an inseticide. Journal of Economic Entomology, Annapolis, v. 18, n. 1, p. 265-267, 1925.

ADEL, M. M. Lufenuron impair the chitin synthesis and development of Spodoptera littoralis Bosid (Lepidoptera: Noctuidae). Journal of Applied Sciences Research, Jordan, v. 8, n. 5, p. 2766-2775, 2012 .

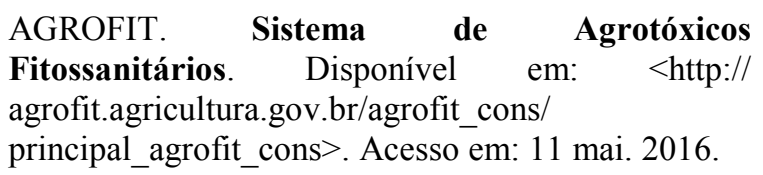

ALBUQUERQUE, G. S.; TAUBER, C. A.; TAUBER, M. J. Chrysoperla externa (Hagen) (Neuroptera: Chrysopidae): Life history and potential for biological control in Central and South America. Biological Control, Montreal, v. 4, n. 1, p. 8-13, 1994.

ATANASSOV, A.; SHEARER, P. W.; HAMILTON, G. Peach pest management programs impact beneficial fauna abundance and Grapholita molesta (Lepidoptera: Tortricidae) egg parasitism and predation. Environmental Entomology, Lanham, v. 32, n. 4, p. 780-788, 2003.

BOTTON, M. et al. Bioecologia, monitoramento e controle da mariposa-oriental na cultura do pessegueiro no Rio Grande do Sul. Bento Gonçalves: Embrapa Uva e Vinho, 2011. 11 p. (Circular técnica, 86).

CASTILHOS, R. V. et al. Selectivity of pesticides used in peach orchards on the larval stage of the predator Chrysoperla externa (Hagen) (Neuroptera: Chrysopidae). Semina: Ciências Agrárias, Londrina, v. 34, n. 6, Sup. 1, p. 3585-3596, 2013.

CASTILHOS, R. V. et al. Seletividade de agrotóxicos utilizados em pomares de pêssego a adultos do predador Chrysoperla externa (Hagen, 1861) (Neuroptera: Chrysopidae). Revista Brasileira de Fruticultura, Jaboticabal, v. 33, n. 1, p. 73-80, 2011.

DE BORTOLI, S. A. et al. Desenvolvimento e capacidade predatória de Chrysoperla externa (Hagen) (Neuroptera: Chrysopidae) em diferentes presas. Revista de Biologia e Ciências da Terra, Campina Grande, v. 6, n. 1, p. 145-152, 2006.

FREITAS, S. O uso de crisopídeos no controle biológico de pragas. In: PARRA, J. R. P. et al. 
(Eds.). Controle biológico no Brasil: parasitoides e predadores. São Paulo: Manole, 2002. cap. 13, p. 209-219.

GODOY, M. S. et al. Seletividade fisiológica de inseticidas em duas espécies de crisopídeos. Pesquisa Agropecuária Brasileira, Brasília, v. 45, n. 11, p. 1253-1258, 2010.

HARAMBOURE, M. Evaluation of tolerance and susceptibility to conventional and biorational insecticides in Chrysoperla externa and C. asoralis (Neuroptera: Chrysopidae). 2016. 167 f. Tese (Joint PhD em Ciências Naturais) - National University of La Plata / Ghent University. La Plata/ Ghent.

HARAMBOURE, M. et al. Toxicity of cypermethrin on the neotropical lacewing Chrysoperla externa (Neuroptera: Chrysopidae). Communications in Agricultural and Applied Biological Sciences, Ghent, v. 78, n. 2, p. 339-344, 2013.

KALAMARAKIS, A. E.; MARKELLOU, E. Efficacy evaluation of plant protection products at EU level: Data requirements and evaluation principles. Journal of Pesticide Science, Tokyo, v. 32, n. 1, p. 1-9, 2007.

MACHADO, A. A.; CONCEIÇÃO, A. R. WinStat Sistema de Análise Estatística para Windows. Universidade Federal de Pelotas, RS. 2007. Versão 2.0 Disponível em: <http://minerva.ufpel.edu.br/ $\sim$ amachado/>. Acesso em: 29 jul. 2013.

MOURA, A. P. et al. Selectivity of pesticides used in integrated apple production to the lacewing, Chrysoperla externa. Journal of Insect Science, Madison, v. 10, n. 121, p. 1-20, 2010.

MULligAN, E. A. et al. Characterisation of adult green lacewing (Chrysoperla carnea) digestive physiology: impact of a cysteine protease inhibitor and a synthetic pyrethroid. Pest Management Science, London, v. 66, n. 3, p. 325-336, 2010.

NAVA, D. E. et al. Insetos e ácaros praga. In: RASEIRA, M. C. B.; PEREIRA, J. F. M; CARvalho, F. L. C. (Eds.) Pessegueiro. Brasília: Embrapa, 2014. cap. 16, p. 433-486.

PATHAN, A. K. et al. Evidence of field-evolved resistance to organophosphates and pyrethroids in Chrysoperla carnea (Neuroptera: Chrysopidae). Journal of Economic Entomology, Annapolis, v. 101, n. 5, p. 1676-1684, 2008.

PATHAN, A. K. et al. Resistance to pyrethroids and organophosphates increased fitness and predation potential of Chrysoperla carnea (Neuroptera:
Chrysopidae). Journal of Economic Entomology, Annapolis, v. 103, n. 3, p. 823-834, 2010.

PETERSON, R. K. D. et al. Mortality risk in insects. Environmental Entomology, Annapolis, v. 38, n. 1, p. 2-10, 2009.

SCHUBER, J. M. et al. Influência de sistemas de produção sobre a ocorrência de inimigos naturais de afídeos em pomares de pessegueiros em Araucária PR. Revista Brasileira de Fruticultura, Jaboticabal, v. 30, n. 2, p. 336-342, 2008.

THOMSON, L. J.; HOFFMANN, A. A. Field validation of laboratory-derived IOBC toxicity ratings for natural enemies in commercial vineyards. Biological Control, Montreal, v. 39 n. 3, p. 507-515, 2006.

VILELA, M. et al. Seletividade de acaricidas utilizados em cafeeiro para larvas de crisopídeos. Revista Ceres, Viçosa, v. 57, n. 5, p. 621-628, 2010.

VIÑUELA, E.; HÄNDEL, U.; VOGT, H. Evaluación en campo de los efectos secundários de dos plaguicidas de origen botánico, una piretrina natural y un extracto de neem, sobre Chrysoperla carnea Steph. (Neuroptera: Chrysopidae). Boletin de Sanidad Vegetal: Plagas, Madrid, v. 22, n. 1, p. 97-106, 1996.

VOGT, H. Effects of pesticides on Chrysoperla carnea Steph. (Neuroptera, Chrysopidae) in the field and comparison with laboratory and semi-field results. IOBC/WPRS Bulletin, Montfavet, v. 17, n. 10, p. 71-82, 1994.

VOGT, H. et al. Laboratory method to test effects of plant protection products on larvae of Chrysoperla carnea (Neuroptera: Chrysopidae). In: CANDOLFI, M. P. et al. (Eds.). Guidelines to evaluate side-effects of plant protection products to non-target arthropods. Reinheim: IOBC/ WPRS, 2000 , v. 1 , cap. 3 , p. $27-44$.

ZONGMAO, C.; HAIBIN, W. Degradation of pesticides on plants surface and its prediction - A case study on tea plant. Environmental Monitoring and Assessment, Berlin, v. 44, p. 303-313, 1997. 